\title{
Women with cancer and COVID-19: an analysis of lethality and clinical aspects in Pernambuco
}

Rafaella Joanna da Silva Caseca Galindo 1

iD https://orcid.org/0000-0003-3460-477X

Lívia Barboza de Andrade 2

iD https://orcid.org/0000-0002-5647-1835

Gabrielle Ribeiro Sena 3

iD https://orcid.org/0000-0002-8430-3599

Lídier Roberta Moraes Nogueira 4

iD https://orcid.org/0000-0002-4619-8580

Tiago Pessoa Ferreira de Lima 5

iD https://orcid.org/0000-0002-1148-4288
Jurema Telles Oliveira Lima 6

(iD https://orcid.org/0000-0003-2671-3570

Flávia Augusta Orange 7

(iD) https://orcid.org/0000-0003-0528-4164

1,4,5,7 Faculdade Pernambucana de Saúde. Av. Mascarenhas de Moraes, 4861 - Imbiribeira. Recife, PE, Brasil. CEP: 51.200-060. E-mail: rafaella.caseca@gmail.com 2,3,6 Instituto de Medicina Integral Prof. Fernando Figueira. Recife, PE, Brasil.

\begin{abstract}
Objectives: to analyze the lethality and clinical characteristics in Pernambuco women with neoplasia that were infected by SARS-CoV-2.

Methods: a cross-sectional, retrospective study with female patients with neoplasm sin the state of Pernambuco registered and made available by the Secretariat of Planning and Management of the State of Pernambuco (SEPLAG PE). Secondary data from public domain notifications and the independent factors associated with death were analyzed through logistic regression. The value of $p<0.25$ was considered significant in the bivariate analysis and for a multivariate analysis, the value of $p<0.05$ was considered significant.

Results: forty-nine women died. The mean age and standard deviation were $58.75 \pm 20.93$ years. $55.86 \%$ of the patients were 60 years old or more. The overall lethality rate was $72.06 \%(C 195 \%=59.8-82.2)$. The most prevalent symptoms were fever $(70.59 \%)$, cough (58.82\%), dyspnea (57.35\%) and $\mathrm{O}_{2}$ saturation less than $95 \%(48.53 \%)$.

Conclusions: female patients, with cancer and infected by SARS-CoV-2 are particularly susceptible to death, regardless of the presence of comorbidities or age, with peripheral $\mathrm{O}_{2}$ saturation $\leq 95 \%$ being the only independent factor associated with death in this group.

Key words Oncology, COVID-19, Pandemic, Risk factors, Women
\end{abstract}

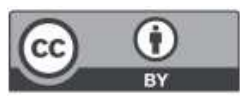




\section{Introduction}

COVID-19 (coronavirus disease) is a disease of zoonotic origin, mainly respiratory, which may cause important systemic limitations. In Brazil, the first case was confirmed in February 26, 2020, and virus dissemination reached high proportions in the country due to its speed of transmission, low testing rates and difficulties to completely block the propagation in a largely heterogeneous population.1,2

With the continuous increase of number of cases worldwide, it was noticed that older age and presence of comorbidities such as diabetes, cardiovascular diseases and cancer are associated with an increase in morbimortality by COVID-19. Cancer, particularly recognized as a global public health problem according to the World Health Organization (WHO), leads individuals to become more susceptible to COVID-19 infection, due to the disease itself or its treatment, thus they present higher risk of severe events and death compared to patients without cancer or yet with another comorbidities. 3,4

If on one hand cancer is an important risk factor for death by COVID-19, on the other hand, female gender seems to be a protective factor.4-7 This protection can be explained by the low prevalence of comorbidities, smoking, alcohol consumption and occupational exposure in this group. ${ }^{4}$ Furthermore, women usually present higher practice of hand hygiene ${ }^{8}$ and are more prone to search for preventive care. ${ }^{9}$ Also, a biological characteristic related to gender is the difference in the angiotensinconverting enzyme 2 (ACE2) receptors, located on the $\mathrm{X}$ chromosome, which grants women higher levels of this enzyme, thus being an additional protective factor against more acute manifestations of COVID-19 infection compared to men. 10-13

Yet, information on mortality in different population groups and regions in Brazil are still not clear, particularly that related to women with cancer and infected by SARS-CoV-2 in underprivileged regions in Brazil, such as the Northeast, which is familiar with other risk factors, such as social vulnerabilities and difficulties in healthcare access. In this way, the aim of this study is to assess mortality and clinical characteristics presented by women with neoplasm and who presented SARS-CoV-2 infection in the State of Pernambuco.

\section{Methods}

Cross-sectional cohort study with retrospective data Cases of COVID-19 confirmed by RT-PCR (Reverse transcription polymerase chain reaction) for SARS-
CoV-2 in female patients were eligible, with neoplasms, notified from February 13 to June 19, 2020 , in the State of Pernambuco and made available by the Secretary of Planning and Management of the State of Pernambuco (SEPLAG PE - Portuguese acronym).

In the FORMSUS, SRAS notification form, severe cases, with or without hospitalization are notified (https://www.cievspe.com/notifique-aqui). The e-SUS sheet, Individual Registration Sheet of the Secretary of Primary Health Care, is used to report mild cases (influenza-like illness) in the population, non-hospitalized patients in general (https://notifica.saude.gov.br). Both show epidemiological data, results of laboratory exams for COVID19 confirmation and evolution of patients.

Both sheets, e-SUS and FORM-SUS, in Excel ${ }^{\odot}$ format, were analyzed by the researchers of this study. Initially, analysis of data consistency was performed, which excluded duplicities and inconsistent data.

For the analysis, were included data regarding age, symptoms and signs including peripheral oxygen saturation lower or equal to $95 \%\left(\mathrm{SpO}_{2}\right.$ $\leq 95 \%$ ), comorbidities, residence locations by Regional Health Management - GERES (Portuguese acronym), date of notification, hospitalization and death.

Symptoms registered in the information systems as [symptoms] or [other symptoms] or [select presented symptoms] or [other symptoms (which)] or even included among comorbidities were grouped in this study in the following categories: Fever, Coryza/Nasal Congestion. Sore Throat, Cough, Dyspnea, $\mathrm{O}_{2}$ saturation $\leq 95 \%$, Diarrhea, Nausea/Vomit, Headache, Myalgia, Anosmia/ Hyposmia or Ageusia Tiredness/Fatigue, Respiratory Distress/Chest Tightness.

In the original sheets, notified comorbidities were grouped in: Cardiovascular Disease, Chronic Respiratory Disease, Chronic Kidney Disease, Diabetes, Overweight/Obesity, Immunosuppression, Chromosomal Disorders and non-informed. The outcome of interest assessed was death.

Statistical analyses were performed in Excel for macOS version 16.16.26 and Epi Info version 7.2. Descriptive data were presented in tables of distribution of frequencies with mean and standard deviation measures. In order to determine independent factors associated with death, logistic regression was used. It was considered significant the value of $p<0.25$ in the bivariate analysis, and for multivariate analysis, $p<0.5$ value was considered significant.

This study analyzed secondary data from public 
domain database, disregarding the appreciation of Research Ethics Committee.

\section{Results}

The e-SUS sheet contained 65,535 registries occurred in the period from February 13 to June 24, 2020 and the Form-SUS, 28, 605 notifications in the period from February 25 to June 19, 2020. 72 patients who met the eligibility criteria were identified, and they were grouped in a single database for further exclusion of duplicities. It was not possible to retrieve or determine the date of occurrence of symptoms for four patients, who were considered losses; thus, 68 patients were considered. The age and standard deviation means (SD) were $58.75 \pm$ 20.93 years and median 61.5 . A proportion of $4.41 \%$ of patients were under 20 years old and $55.86 \%$ had 60 years of age or more.

In regards of municipalities of residence, GERES 1- Recife (65.71\%), followed by GERES 2 - Limoeiro (8.82\%) and GERES 9 - Oricuri (7.35\%) notified more patients. GERES 4 - Caruaru notified $5.88 \%$ if cases, GERES 10 - Afogados da Ingazeira $4.41 \%$, GERES 12 - Goiana $2.94 \%$ and GERES 3 and 6 notified $1.47 \%$ of cases each one. $2.94 \%$ of patients were from other State (Table 1).

It was also observed that $60.29 \%$ of patients were followed by SUS (Portuguese acronym for Unified Health System), 25\% in private hospitals and $14.71 \%$ did not have their medical care locations informed. In relation to deaths, $61.22 \%$ occurred in public health units, $22.45 \%$ in private units and $2.04 \%$ in households. $14.29 \%$ of death locations were not informed (Table 1).

The global mortality rate was $72.06 \%$ (CI95\% $=$ $59.8-82.2$ ). Table 2 shows mortality rate by age, being $50-59$ years $(81.82 \%$ CI95\% $=8.7-32.0), 60$ 69 years $(76.47 \% \mathrm{CI} 95 \%=14.9-41.0), 70-79$ years $(90.00 \% \mathrm{CI} 95 \%=8.7 \%-32.0)$, and from 80 years on $(90.91 \%$ CI95\% $=10.2-34.3)$. Until the time of data collection, $16.18 \%$ were hospitalized in isolated beds, $10.29 \%$ have recovered, and $1.47 \%$ were in home isolation.

It was also observed that the mean of days between the onset of first symptoms and death was of $12.32 \pm 10.13$ days (SD) and median 9.00. It is worth highlighting that between 50 and 79 years the mean of days were the highest, being 19.1 days between 50-59 years, 11.84 days between 60-69 years and 11.77 days between $70-79$ years. 2 patients between 50 and 59 years, evolved, the first with 48 days and the other with 55 days since the onset of symptoms until the outcome (Table 2).
There was no registry of signs/symptoms in $1.47 \%$ of cases. The most prevalent symptoms in the analyzed sample were fever $(70.59 \%)$, cough $(58.82 \%)$, dyspnea $(57.35 \%)$ and peripheral saturation of $\mathrm{O}_{2} \leq 95 \%$ (48.53\%) (Table 3).

Other comorbidities were present in $39.71 \%$ of patients, being more frequent Cardiovascular Diseases (27.94\%), Diabetes Mellitus (13.24\%) and Chronic Respiratory Disease (8.82\%) (Table 3). Furthermore, $26.7 \%$ of patients presented only one comorbidity associated with cancer, $13.23 \%$ presented two or more associated comorbidities. The association of cardiovascular diseases and diabetes was observed in $100 \%$ of cases with two or more comorbidities. A proportion of $44.90 \%$ of patients who died had comorbidities, of which $32.65 \%$ had cardiovascular diseases and $14.29 \%$ diabetes.

The crude and adjusted analysis of factors related to death identified the presence of peripheral $\mathrm{O}_{2}$ saturation lower or equal to $95 \%$ as the only independent factor associated with death $(\mathrm{OR}=0.21$; CI95\% $=0.04-0.92 ; p=0.039)$ (Table 4$)$.

\section{Discussion}

This study describes clinical findings of 68 COVID19 cases confirmed by RT-PCR for SARS-CoV-2 between women with cancer during the first three months of the epidemic in Pernambuco (03/12 to $06 / 19 / 20$ ), one of the epicenters of the disease in Brazil. Secondary data from notification sheets of patients attended in the basic care or hospitalized patients were used, when higher restriction and indication of RT-PCR tests occurred. Although it is the main limitation of this study, such tool remains of great usefulness for the epidemiological description of cases.

Predominant symptoms and signs were fever, cough, dyspnea and $\mathrm{O}_{2}$ saturation lower or equal to $95 \%$. The global mortality of $72.06 \%$ was high, as well as the mortality rate by age. The only independent factor associated with death was $\mathrm{O}_{2}$ saturation lower or equal to $95 \%$.

The mean age of patients was $58.75 \pm 20.93$ years and $55.86 \%$ of patients had 60 years or more. The mean age involving oncologic patients with COVID-19 in China varied from 63.1 to 65 years, being slightly higher to the mean found in this study.2,14 In this study, age did not indicate o be a variable associated with death. This could be explained, primarily, by the sample size, but also by the presence of cancer, which would rise the risk of death outcome by itself.

Whilst the mortality rate by COVID-19 in Brazil, 


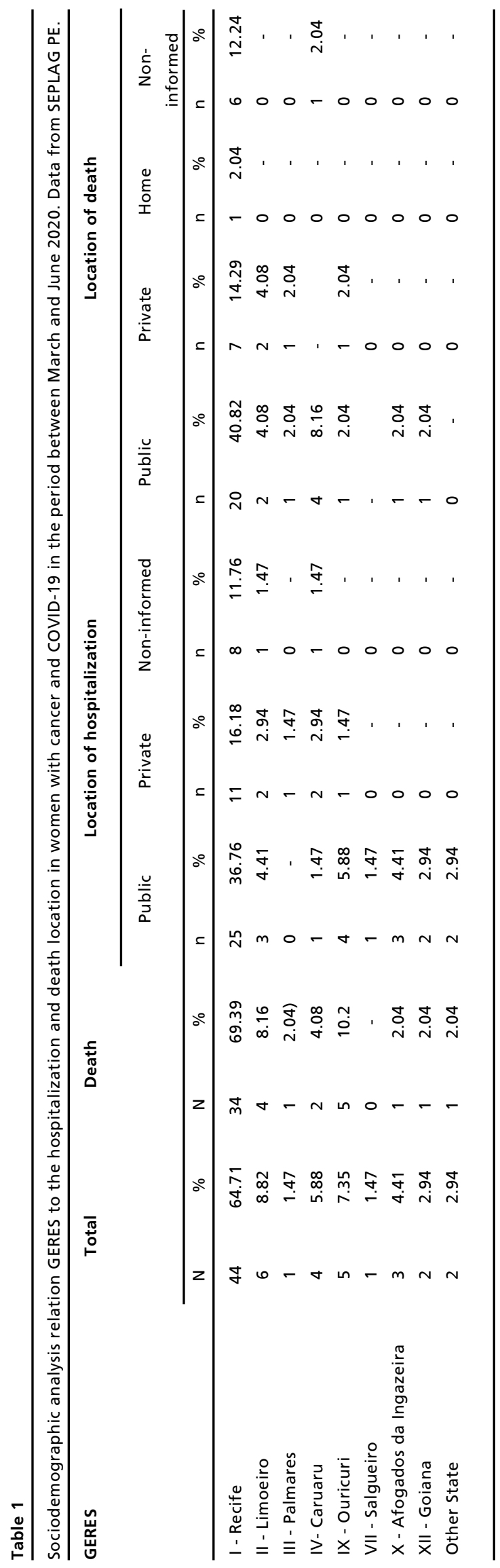




\section{Table 2}

Mean relation of days between the onset of the first symptom and death and mortality by age groups of women with cancer and COVID-19 in the period between March and June 2020. Data from SEPLAG PE.

\begin{tabular}{lccc}
\hline Age group (years) & Mean of days between first symptom and death & \multicolumn{2}{c}{ Mortality } \\
\cline { 2 - 4 } & & $\mathrm{n}$ & \multicolumn{2}{c}{$\%$} \\
\hline $0-19$ & $6 \pm 0.00$ & 7 & 43.33 \\
$20-49$ & $10 \pm 5.53$ & 9 & 81.82 \\
$50-59$ & $19.11 \pm 19.29$ & 13 & 76.47 \\
$60-69$ & $11.84 \pm 5.98$ & 9 & 90.00 \\
$70-79$ & $11.77 \pm 8.36$ & 10 & 90.91 \\
$>80$ & $9.6 \pm 4.72$ & & \\
\hline
\end{tabular}

\section{Table 3}

Prevalence of comorbidities, signs, and symptoms of women with cancer and COVID-19 in the period between March and June 2020. Data from SEPLAG PE.

\begin{tabular}{|c|c|c|c|c|}
\hline \multirow[t]{4}{*}{ Variables } & \multicolumn{4}{|c|}{ Cases } \\
\hline & \multicolumn{2}{|c|}{ Total } & \multicolumn{2}{|c|}{ Deaths } \\
\hline & $\mathrm{N}$ & $\%$ & $\mathrm{~N}$ & $\%$ \\
\hline & 68 & 100.0 & 49 & 100.0 \\
\hline \multicolumn{5}{|l|}{ Signs and Symptoms } \\
\hline Fever & 48 & 70.59 & 36 & 73.47 \\
\hline Cough & 40 & 58.82 & 27 & 55.10 \\
\hline Dyspnea & 39 & 57.35 & 32 & 65.31 \\
\hline Saturation of $\mathrm{SpO}_{2}<95 \%$ & 33 & 48.53 & 29) & 59.18 \\
\hline Sore throat & 11 & 16.18 & 8 & 16.33 \\
\hline Nausea/ Vomit & 7 & 10.29 & 6 & 12.24 \\
\hline Coryza/ Nasal Congestion & 5 & 7.35 & 1 & 2.04 \\
\hline Diarrhea & 4 & 5.88 & 4 & 8.16 \\
\hline Headache & 3 & 4.41 & 1 & 2.04 \\
\hline Myalgia & 3 & 4.41 & 0 & - \\
\hline Anosmya/ Hyposmia or Ageusia & 1 & 1.47 & 1 & 2.04 \\
\hline Tiredness/ Fatigue & 1 & 1.47 & 1 & 2.04 \\
\hline \multicolumn{5}{|l|}{ Number of comorbidities } \\
\hline 1 & 18 & 26.47 & 16 & 32.65 \\
\hline 2 & 6 & 8.82 & 4 & 8.16 \\
\hline 3 & 3 & 4.41 & 2 & 4.08 \\
\hline Non-informed & 41 & 60.29 & 27 & 55.10 \\
\hline \multicolumn{5}{|l|}{ Comorbidities } \\
\hline Cardiovascular diseases & 19 & 27.94 & 16 & 32.65 \\
\hline Diabetes & 9 & 13.24 & 7 & 14.29 \\
\hline Chronic respiratory disease & 6 & 8.82 & 5 & 10.20 \\
\hline Chronic kidney disease & 2 & 2.94 & 1 & 2.04 \\
\hline Overweight/ obesity & 1 & 1.47 & 0 & - \\
\hline Chromosomal disorders & 1 & 1.47 & 1 & 2.04 \\
\hline
\end{tabular}




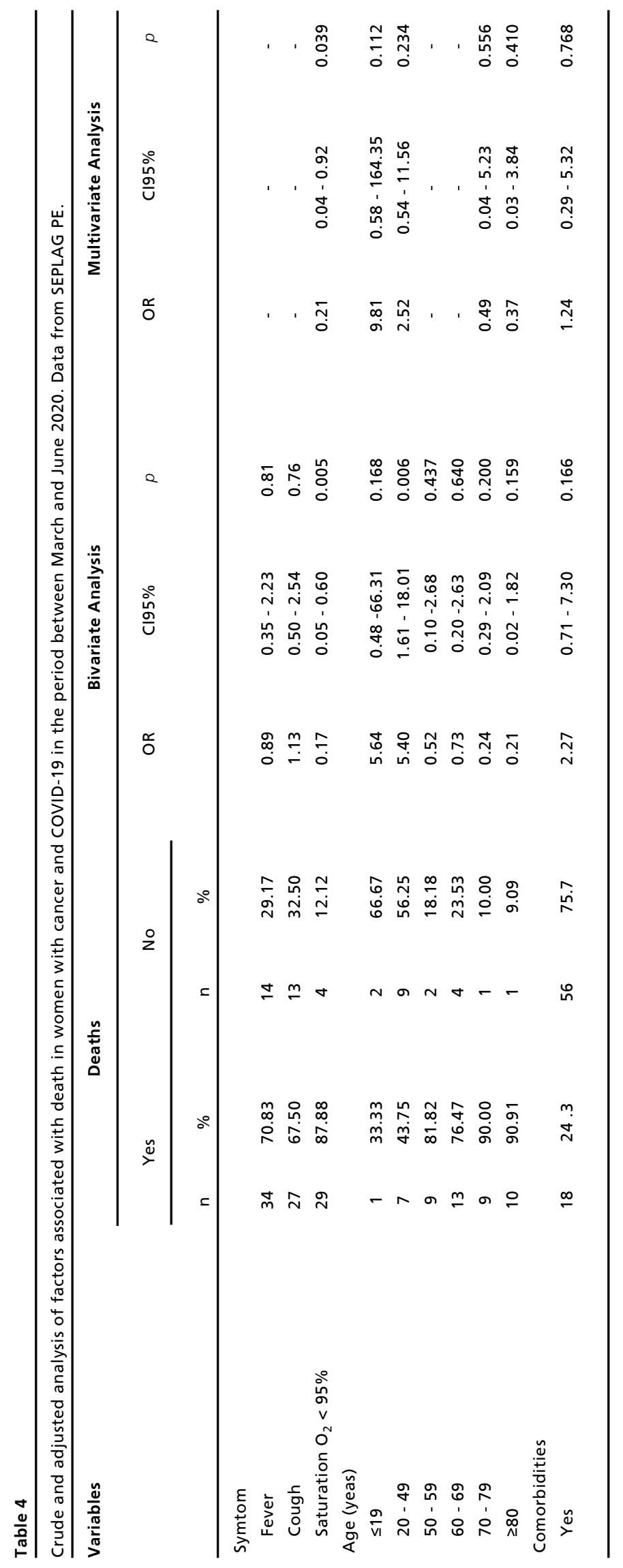


in the same period of the data collected, was around $5 \%$ and in Pernambuco, $8 \%, 15$ the mortality for all oncologic patients in the state was $79.38 \% .16-18$ Considering both mortality for the oncologic patients group in Pernambuco and the mortality for the sample, these were far higher than those found in the literature, which varied between $5.6 \%$ and $28.6 \% .14,19$ The analysis of mortality by age group showed a clear ascending curve from 60 years on, and, comparatively, these data appeared to be distinct of those from Italy, where rates of fatal cases, considering oncologic and non-oncologic patients with COVID-19, rises exponentially after 70 years of age: $12.5 \%$ in $70-79$ span, $19.7 \%$ in the 80 90 years span and $22.7 \%$ after 90 years. 20 It is important to highlight that these high mortality rates reflect a period when there was no broad availability of tests, besides, the sample size might have influenced the percentages found.

Similar to the literature, $39.71 \%$ of women presented comorbidities, and $44.90 \%$ of patients who died had some comorbidity. 14 Although several articles demonstrate that morbidities were strong risk factors for adverse clinical outcomes such as death, the presence of comorbidity was not considered an independent risk factor associated with death in this study, as well as in other Chinese study. 6,21-26 Once more, the sample size might have influenced the result, so as the absence of data and the precision of description of these in the database. Moreover, cancer also may be strongly related to death risk, reducing the influence of other comorbidities.

In regards of the symptoms, fever, cough, dyspnea and saturation of $\mathrm{SpO}_{2} \leq 95 \%$ were the most prevalent, agreeing with data from the literature.6,14,27 According to the Ministry of Health, the diagnosis of SRAS is considered, for every individual, of any age, with influenza-like illness and who presents signs of hypoxemia, as the saturation of $\mathrm{SpO}_{2} \leq 95 \%$ in environmental air.28 The saturation of $\mathrm{SpO}_{2} \leq 95 \%$, namely, was the only independent factor associated with death, after multivariate analysis, agreeing with the literature. 6

The mean of time between the onset of first symptoms and death was lower than that find on a Chinese study, with a mean of 16 days $(9.0-22.3) .14$ Some hypotheses may justify this difference of days in both studies, as for example, the greater severity of Brazilian/ Pernambuco patients, difficulty of access to healthcare, slowness of diagnosis process and regulation for services of higher complexity, social vulnerabilities, or even lack of beds in ICUs and/or mechanic ventilators. 29
The present study has limitations such as the small sample and limited data regarding types of cancers and staging, besides information on the type of treatment conducted. Furthermore, comparisons between patients with and without cancer infected by COVID-19 may reveal additional information, although they were not performed in this study. Thus, further studies with broader samples and prospective study designs are necessary to explore even more the risk factors and severe events in women with cancer and COVID-19.

Therefore, it is concluded that female patients, with cancer and infected by SARS-CoV-2 are particularly susceptible to death, independently of comorbidities or age, being peripheral $\mathrm{O}_{2}$ saturation $\leq 95 \%$ the only independent factor associated with death in this group.

\section{Acknowledgments}

The authors thanks all health professionals involved with care if patients with COVID-19 and SEPLAG PE for the availability of data.

\section{Authors' contribution}

Galindo RJSC, Nogueira LRM, Sena GR and Andrade LB: Conception and planning of the study. Lima TPF, Lima JTO and Orange FA: revision of the manuscript. All authors approved the final version of the article. 


\section{References}

1. Frater JL, Zini G, d'Onofrio G, Rogers HJ. COVID-19 and the clinical hematology laboratory. Int J LabHematol. 2020; 42: 11-18.

2. Brasil. Ministério da Saúde. Boletim COE COVID-19 [Internet]. 2020 [acesso 26 jul. 2020]. Disponível em: https://portalarquivos.saude.gov.br/images/pdf/2020/April/ 21/BE13---Boletim-doCOE.pdf

3. Santos Thuler LC, de Melo AC. Sars-CoV-2/Covid-19 em Pacientes com Câncer. Rev Bras Cancerol [Internet]. 2020 [acesso 04 set. 2020]; 66 (2): e-00970. Disponível em: https://rbc.inca.gov.br/revista/index.php/revista/article/vie w/970

4. Liang W, Guan W, Wang W, Li J, Xu K, Li C, Ai Q, Lu W, Liang H, Li S, He J. Cancer patients in SARS-CoV-2 infection: a nationwide analysis in China. Lancet Oncol. 2020 21 (3): 335-7.

5. INCA (Instituto Nacional do Câncer José Alencar Gomes da Silva). Estimativa 2020: incidência de câncer no Brasil Rio de Janeiro; 2019.

6. Global Health 50/50. The COVID-19 sex-disaggregated data tracker [online]. 2020 [acesso 26 jul. 2020]. Disponível em: https://globalhealth5050.org/the-sexgender-and-covid-19-project

7. Xie J, Tong Z, Guan X, Du B, Qiu H. Clinical Characteristics of Patients Who Died of Coronavirus Disease 2019 in China. JAMA Netw Open. 2020; 3 (4) e205619

8. Guan WJ, Ni ZY, Hu Y, Liang WH, Ou CQ, He JX, Liu L, Shan H, Lei CL, Hui DSC, Du B, Li LJ, Zeng G, Yuen KY, Chen RC, Tang CL, Wang T, Chen PY, Xiang J, Li SY, Wang JL, Liang ZJ, Peng YX, Wei L, Liu Y, Hu YH, Peng P, Wang JM, Liu JY, Chen Z, Li G, Zheng ZJ, Qiu SQ, Luo J, Ye CJ, Zhu SY, Zhong NS. Clinical characteristics of Coronavirus Disease 2019 in China. N Engl J Med. 2020; 382: 1708-20.

9. Sharma G, Volgman AS, Michos ED. Sex Differences in Mortality From COVID-19 Pandemic: Are Men Vulnerable and Women Protected? JACC Case Reports. 2020; 2(9) 1407-10.

10. Durell Johnson H, Sholcosky D, Gabello K, Ragni R, Ogonosky N. Sex differences in public restroom handwashing behavior associated with visual behavior prompts. Percept Mot Ski. 2003; 1 (3): 805-10.

11. Bertakis KD, Azari R, Helms LJ, Callahan EJ, Robbins JA. Gender differences in the utilization of health care services. J Fam Pr. 2000; 49 (2): 147-52

12. Wang K, Gheblawi M, Oudit GY. Angiotensin Converting Enzyme 2: A Double-Edged Sword. Circulation. 2020; 142 . 426-8

13. Chen L, Li X, Chen M, Feng Y, Xiong C. The ACE2 expression in human heart indicates new potential mechanism of heart injury among patients infected with SARS CoV-2. Cardiovasc Res. 2020; 116 (6): 1097-1100.

14. Batlle D, Wysocki J, Satchell K. Soluble angiotensinconverting enzyme 2: a potential approach for coronavirus infection therapy? Clin Sci. 2020; 134 (5): 543-5.

15. Bhatia K, Zimmerman MA, Sullivan JC. Sex differences in angiotensin-converting enzyme modulation of Ang (1-7) levels in normotensive WKY rats. Am J Hypertens. 2013; 26 (5): 591-8.

16. CIEVS/PE (Centro de Informações Estratégicas de Vigilância em Saúde de Pernambuco). Novo Coronavírus (COVID-19): Atualizações Epidemiológicas [online]. 2020 [acesso 09 set. 2020]. Disponível em: https://www.cievspe.com/novo-coronavirus-2019-ncov

17. Zhang L, Zhu F, Xie L, Wang C, Wang J, Chen R, Jia P, Guan HQ, Peng L, Chen Y, Peng P, Zhang P, Chu Q, Shen Q, Wang Y, Xu SY, Zhao JP, Zhou M. Clinical characteristics of COVID-19-infected cancer patients: a retrospective case study in three hospitals within Wuhan, China. Ann Oncol. 2020; 31 (7): 894-901.

18. Governo do Estado de Pernambuco. Secretaria de Planejamento e Gestão. 2020 [acesso 9 set. 2020]. Disponível em: https://www.seplag.pe.gov.br

19. Epidemiology Working Group for NCIP Epidemic Response, Chinese Center for Disease Control and Prevention. [The epidemiological characteristics of an outbreak of 2019 novel coronavirus diseases (COVID-19) in China]. Zhonghua Liu Xing Bing XueZaZhi. 2020; 41 (2): 145-51. Chinês.

20. Livingston E, Bucher K. Coronavirus Disease 2019 (COVID-19) in Italy. JAMA. 2020; 323 (14): 1335.

21. Huang C, Wang Y, Li X, Ren L, Zhao J, Hu Y, Zhang L, Fan G, Xu J, Gu X, Cheng Z, Yu T, Xia J, Wei Y, Wu W, Xie X, Yin W, Li H, Liu M, Xiao Y, Gao H, Guo L, Xie J, Wang G, Jiang R, Gao Z, Jin Q, Wang J, Cao B. Clinical features of patients infected with 2019 novel coronavirus in Wuhan, China. Lancet. 2020; 395 (10223): 497-506.

22. Chen N, Zhou M, Dong X, Qu J, Gong F, Han Y, Qiu Y, Wang J, Liu Y, Wei Y, Xia J, Yu T, Zhang X, Zhang L. Epidemiological and clinical characteristics of 99 cases of 2019 novel coronavirus pneumonia in Wuhan, China: a descriptive study. Lancet. 2020; 395 (10223): 507-13.

23. Liu J, Liu Y, Xiang P, Pu L, Xiong H, Li C, Zhang M, Tan J, Xu Y, Song R, Song M, Wang L, Zhang W, Han B, Yang L, Wang X, Zhou G, Zhang T, Li B, Wang Y, Chen Z, Wang X. Neutrophil-to-Lymphocyte Ratio Predicts Severe Illness Patients with 2019 Novel Coronavirus in the Early Stage. 2020 [acesso 15 set. 2020]. Epub 12 Fev 2020. Disponível em:

https://www.medrxiv.org/content/10.1101/2020.02.10.2002 1584v1.full.pdf

24. Jia Ma, Jing Yin, Yu Qian, Yuan Wu. Clinical characteristics and prognosis in cancer patients with COVID-19: A single center's retrospective study. J Infect. 2020; 81 (12): 318-56.

25. Guan WJ, Liang WH, Zhao Y, Liang HR, Chen ZS, Li YM, Liu XQ, Chen RC, Tang CL, Wang T, Ou CQ, Li L, Chen PY, Sang L, Wang W, Li JF, Li CC, Ou LM, Cheng B, Xiong S, Ni ZY, Xiang J, Hu Y, Liu L, Shan H, Lei CL, Peng YX, Wei L, Liu Y, Hu YH, Peng P, Wang JM, Liu JY, Chen Z, Li G, Zheng ZJ, Qiu SQ, Luo J, Ye CJ, Zhu SY, Cheng LL, Ye F, Li SY, Zheng JP, Zhang NF, Zhong NS, He JX. Comorbidity and its impact on 1590 patients with COVID-19 in China: a nationwide analysis. Eur Respir J. 2020; 55 (5): 2000547. 
26. Dantas Ferreira J, da Silva de Lima FC, Pinto Oliveira JF, de Camargo Cancela M, de Oliveira Santos M. Covid-19 e Câncer: Atualização de Aspectos Epidemiológicos. Rev Bras Cancerol. 2020 [acesso 29 jul. 2020]; 66 (Tema Atual): e-1013. Disponível em: https://rbc.inca.gov.br/revista/index.php/revista/article/vie $\mathrm{w} / 1013$

27. Yang G, Zhang H, Yang Y. Challenges and Countermeasures of Integrative Cancer Therapy in the Epidemic of COVID19. Sage Journals - Integr Complement Med. 2020; 19: $175-244$.
28. Brasil. Ministério da Saúde/SAPS. Protocolo de Manejo Clínico do Coronavírus (COVID-19) na Atenção Primária à Saúde. IFF/Fiocruz [Internet]. 2020 [acesso 16 set. 2020]. Disponível em: https://portaldeboaspraticas.iff.fiocruz.br/biblioteca/protocolo-de-manejo-clinico-do-coronavirus-covid-19-naatencao-primaria-a-saude/

29. Silveira Moreira R. COVID-19: unidades de terapia intensiva, ventiladores mecânicos e perfis latentes de mortalidade associados à letalidade no Brasil. Cad Saúde Pública. 2020; 36 (5): e00080020.

Received on September 27, 2020

Approved on November 10, 2020

ERRATA:

In Page S159, Results, 8th Paragraph,

Where it reads: The crude and adjusted analysis of factors related to death identified the presence of peripheral $\mathrm{O}_{2}$ saturation lower or equal to $95 \%$ as the only independent factor associated with death $(\mathrm{OR}=0.21 ; \mathrm{Cl} 95 \%=0.04-0.92$; $p=0.039$ (Tabela 4).

Reading: The crude and adjusted analysis of factors related to death, identified the presence of peripheral $\mathrm{O}_{2}$ saturation less than or equal to $95 \%$ as the only risk factor associated with death $(O R=5.73 ; C l 95 \%=1.12-20.08 ; p=0.035)$. On the otherhand, the age groups, 19 years or younger, $(\mathrm{OR}=0.07 ; \mathrm{Cl} 95 \%=0.00-1.01 ; p=0.051)$ and 20 to 49 years old $(\mathrm{OR}=$ $0.27 ; \mathrm{Cl} 95 \%=0.07-1.04 ; p=0.057$ ) were identified as protective factors related to death (Table 4 ).

In Page S159, Discussion, 2nd Paragraph

Where it reads: The only independent factor associated with death was $\mathrm{O}_{2}$ saturation lower or equal to $95 \%$.

Reading: The only independent factor associated with higher death risk was $\mathrm{O}_{2}$ saturation less than or equal to $95 \%$. Less than 50 years old was considered a protective factor for death.

In Page S163, Discussion, 6th Paragraph,

Where it reads: The saturation of $\mathrm{SpO}_{2} \leq 95 \%$, namely, was the only independent factor associated with death, after multivariate analysis, agreeing with the literature. 6

Reading: $\mathrm{SpO}_{2}$ saturation $\leq 95 \%$, inclusively was the only independent factor associated with death risk, after multivariable analysis, in accordance with the literature. ${ }^{6}$

In Page S163, Discussion, 9th Paragraph,

Where it reads: Therefore, it is concluded that female patients, with cancer and infected by SARS-CoV-2 are particularly susceptible to death, independently of comorbidities or age, being peripheral $\mathrm{O}_{2}$ saturation $\leq 95 \%$ the only independent factor associated with death in this group.

Reading: Therefore, it concludes that female patients with cancer and infected with SARS-CoV-2 are particularly susceptible to death, regardless of the presence of comorbidities, with peripheral $\mathrm{O}_{2}$ saturation $\leq 95 \%$ being the only independent factor associated with higher risk of death in this group. Less than 50 years old was considered a protective factor for death in this group of patients. 


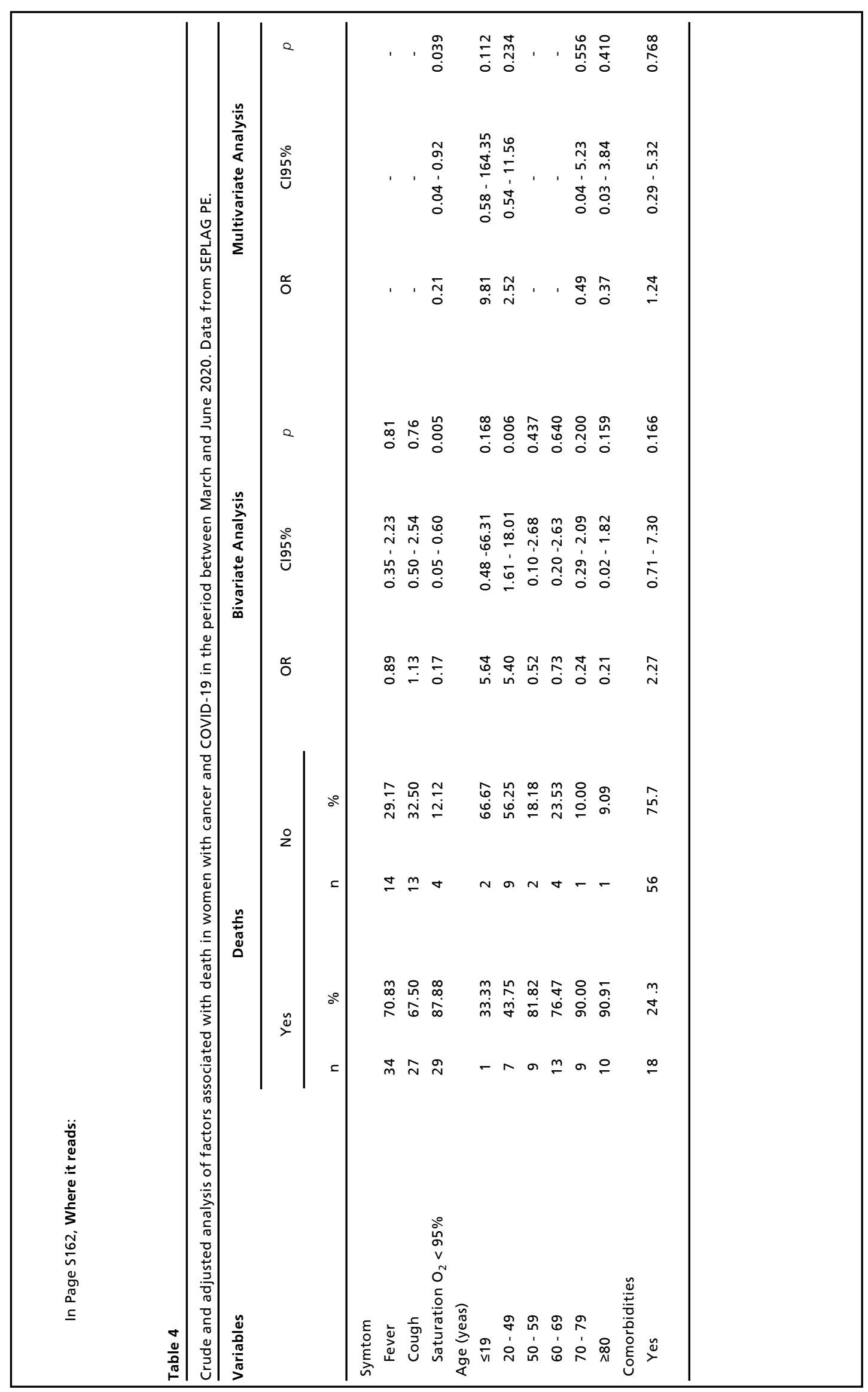




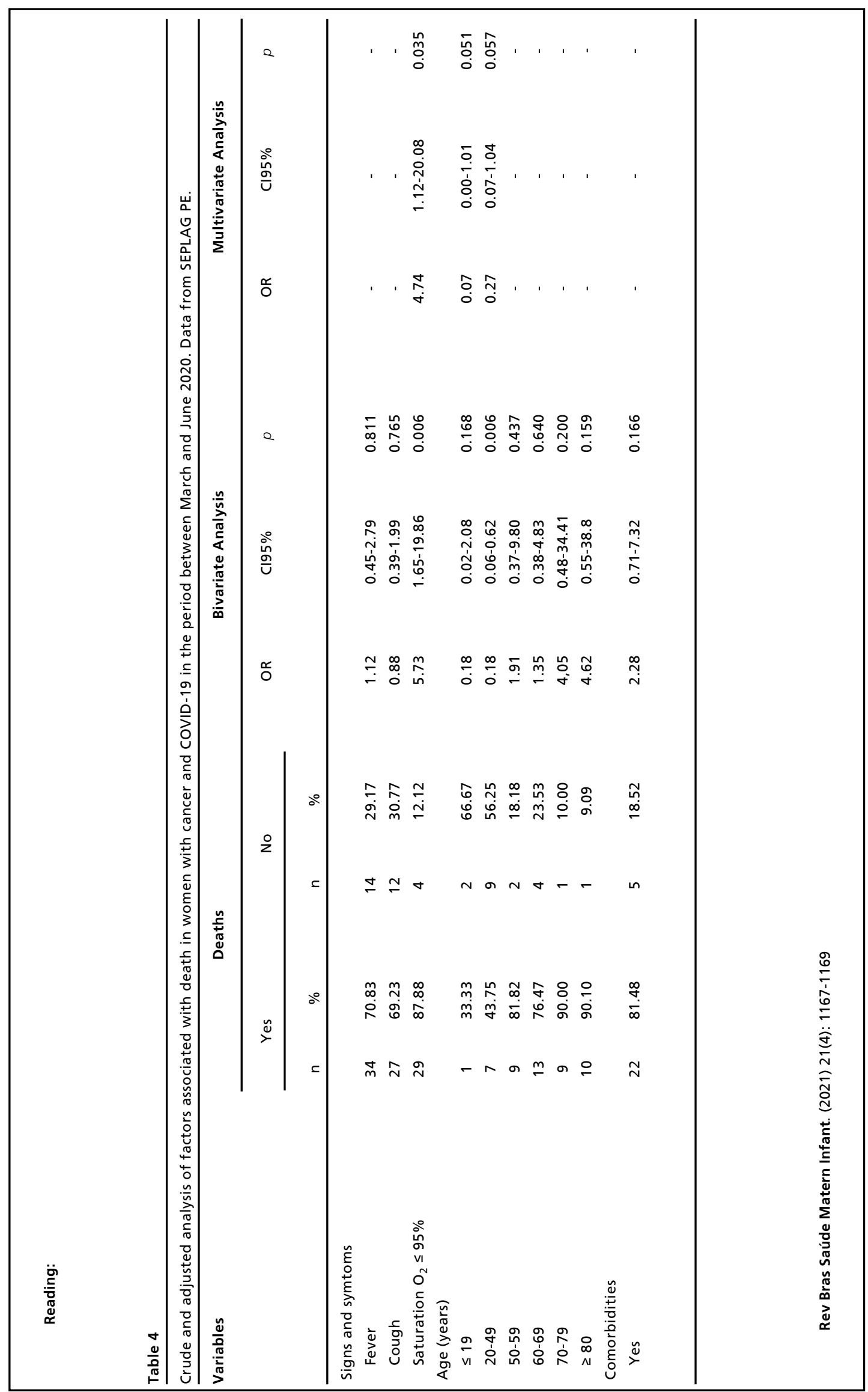

